\title{
Retrospective Evaluation of Incidental Adnexal Masses Encountered During Cesarean Section
}

\section{Sezaryen Sırasında Karşılaşılan Adneksiyel Kitlelerin Retrospektif Değerlendirilmesi}

\author{
(D) Semra Yüksel1, (D) Cemre Alan²
}

${ }^{1}$ University of Health Sciences Turkey, Başakşehir Çam and Sakura City Hospital, Clinic of Obstetrics and Gynecology, İstanbul, Turkey

${ }^{2}$ Necmettin Erbakan University Meram Faculty of Medicine, Department of Obstetrics and Gynecology, Konya, Turkey

\section{Abstract}

Objective: Incidental adnexal masses can be present during cesarean section and management options differ according to the properties of the mass. The objective of this study was to outline and discuss the clinical features and management of adnexal masses that were encountered during a cesarean section.

Method: Records of 7,063 women who had cesarean section between November 2014 and December 2019 in a tertiary center were reviewed retrospectively. Sixty-four women who had an incidental adnexal mass and a pathology report were enrolled to this study.

Results: The incidence of adnexal masses that detected at cesarean section was found as $0.9 \%$. The pathologic diagnoses of the masses were as follows: The non-neoplastic group: Paratubal or paraovarian cyst (25 women, 39\%), simple serous cyst (7 women, 11\%) and corpus luteum cyst (4 women, $8 \%$ ); the neoplastic group: Mature cystic teratoma (11 women, 17\%), mucinous cystadenoma ( 5 women, $8 \%$ ) and adenofibroma (3 women, 5\%). All the women in the non-neoplastic group had undergone cystectomy. Sixteen of women (72\%) in the neoplastic group had undergone cystectomy and 6 of them (28\%) had undergone salpingo-oopherectomy. There was no perioperative and postoperative the complication in any of the patients.

Conclusion: Surgical intervention in women who had incidental adnexal masses during cesarean section does not increase complication rate.

Keywords: Adnexal disease, cesarean section, incidental finding, pregnancy

\section{Öz}

Amaç: Sezaryen sırasında insidental olarak adneksiyal kitle tespit edilebilir ve yönetim şekli kitlenin özelliklerine göre değişiklik gösterir. Bu çalışmanın amacı, sezaryen sırasında karşılaşılan adneksiyal kitlelerin özelliklerini ve yönetimini analiz etmektir.

Yöntem: Üçüncü basamak merkezde Kasım 2014-Aralık 2019 tarihleri arasında sezaryen olan 7.063 hastanın kayıtları retrospektif olarak incelendi. Sezaryen sırasında insidental adneksiyel kitle saptanan ve patolojisi mevcut olan 64 hasta çalışmaya dahil edildi.

Bulgular: Sezaryen sırasında insidental adneksiyal kitle oranı \%0,9 olarak bulundu. Non-neoplastik grubun patolojilerine baktığımızda en sık paratubal veya paraovarian kistler (25 hasta, \%39), 2. en sık basit seröz kist (7 hasta, \%11) ve 3. en sık korpus luteum kisti (4 hasta, \%6) olduğu görüldü. Neoplastik olan grupta ise en sık matur kistik teratom (11 hasta, \%17), sonrasında müsinöz kistadenom (5 hasta, \%8) ve adenofibrom (3 hasta, \%5) izlendi. Non-neoplastik grubun tamamına kistektomi yapıldı. Neoplastik grupta ise hastalardan 16'sına kistektomi (\%72), 6'sına salpingo-ooferektomi (\%28) yapıldı. Cerrahi yapılan hastalarda perioperatif ve post-operatif komplikasyon izlenmedi.

Sonuç: Sezaryen sırasında karşılaşılan adneksiyal kitlelere cerrahi müdahale yapılması komplikasyon riskini artırmamaktadır.

Anahtar kelimeler: Adneksiyal hastalık, gebelik, insidental bulgu, sezaryen

\section{Introduction}

Adnexal masses, which are described as masses of the ovary, fallopian tube, or surrounding tissues, can be encountered in pregnancy or during cesarean section and its prevalence changes between $1 / 81$ and $1 / 8.000$ (1). Nowadays, increased number of adnexal masses during pregnancy can

Address for Correspondence: Cemre Alan, Necmettin Erbakan University Meram Faculty of Medicine, Department of Obstetrics and Gynecology, Konya, Turkey

E-mail: drcemrealan@gmail.com ORCID: orcid.org/0000-0002-6276-1345 Received: 10.01.2022 Accepted: 07.02.2022

Cite this article as: Yüksel S, Alan C. Retrospective Evaluation of Incidental Adnexal Masses Encountered During Cesarean Section. Bagcilar Med Bull 2022;7(1):38-42

${ }^{\odot}$ Copyright 2022 by the Health Sciences University Turkey, Bagcilar Training and Research Hospital Bagcilar Medical Bulletin published by Galenos Publishing House. 
be diagnosed with the widespread use of ultrasonography in routine prenatal care. Adnexal masses are categorized as simple or complex to evaluate the type of mass as benign or malignant. Ovarian cancer, as a second most common gynecological cancer encountered in pregnancy, was reported in $0.49 \%$ of the adnexal masses $(2,3)$.

When an adnexal mass was detected during pregnancy, expectant management or elective surgery at second trimester can be preferred according to the properties of the mass $(1,4)$. When elective surgery was preferred, the risk of preterm birth was reported more in laparotomy than in laparoscopy (11\% vs $2 \%$, respectively) (1). Furthermore, postoperative complication rate was reported as $16 \%$ after laparotomy (5).

Adnexal masses in pregnant women may not be diagnosed during pregnancy up to $50 \%$ to $70 \%$ of patients who come to routine prenatal care $(6,7)$. Transabdominal ultrasonography is preferred more than transvaginal ultrasonography at earlier times of gestation and/or most of the adnexal masses that are smaller than $5 \mathrm{~cm}$ are asymptomatic. Hence, some of the adnexal masses can be diagnosed first time during cesarean section. Incidental adnexal masses may present management dilemmas for clinicians during cesarean section.

Our aim in this study is to evaluate the properties and surgical management of the adnexal masses encountered during cesarean section.

\section{Materials and Methods}

The patients who had a cesarean section $(n=7,063)$ in our hospital between November 2014 and September 2019 were evaluated retrospectively. The women who had an incidental adnexal mass during cesarean section and had a definitive pathology report were enrolled. The ethical approval was obtained from a tertiary center (no: 135, 2020). The authors complied with the World Medical Association Declaration of Helsinki regarding the ethical conduct of research involving human subjects and/or animals.

The clinical and pathological data and the results of the patients were recorded. Exclusion criteria were preoperative diagnosis of adnexal mass, intraligamentary myoma, and cases of ovarian cyst aspiration

Maternal age, gravida, parity, gestational age at the time of cesarean section, cesarean indication, perioperative complications, location, and size of the adnexal mass, surgical procedure (cystectomy or salpingooophorectomy), and definitive pathologies were evaluated. The size of the mass was taken as the average of the two longest diameters.

\section{Statistical Analysis}

Statistical analyses were performed with SPSS 22.0 for Windows (IBM SPSS Statistics, Chicago, IL, USA). Categorical data were given as numbers and percentages, and numerical data as mean \pm standard deviation or median (minimum-maximum).

\section{Results}

A total of sixty-four women $(0.9 \%)$ underwent a surgical procedure during cesarean section due to adnexal mass. The mean age of the patients was $30.2 \pm 6$ years, the median parity was $1.5(0-5)$, and the mean gestational age was $37.7 \pm 2.2$ (Table 1). The most common indication for cesarean section was previous cesarean section (38 patients, $60 \%$ ) (Table 2). Cesarean section was performed in 2 of the patients $(3.1 \%)$ in the preterm period ( $<37$ weeks) due to severe preeclampsia. Only one of the patients underwent cesarean section due to acute abdomen (ovarian torsion).

Sixty seven percent of the cases were in the non-neoplastic group and $33 \%$ of them were in the neoplastic group. Table 3 and Table 4 show the properties of the neoplastic and non-neoplastic groups. The most common pathologies found in non-neoplastic group were para-tubal or paraovarian cysts (25 patients, 39\%), simple serous cyst (7 patients, $11 \%$ ), and corpus luteum cyst (4 patients, $6 \%$ ),

Table 1. Demographic properties of the study group

\begin{tabular}{llll} 
& Mean \pm SD & Minimum & Maximum \\
Age & $30.2 \pm 6.6$ & 15 & 42 \\
Parity & $1.5 \pm 1.1$ & 0 & 5 \\
Gestational age & $37.7 \pm 2.2$ & 27 & 41 \\
Hospital stay (days) & $3.25 \pm 2.5$ & 2 & 25 \\
\hline SD. Standard deviation & & &
\end{tabular}

Table 2. Cesarean indications of the patients

\begin{tabular}{ll} 
& $\mathbf{n}(\%)$ \\
\hline CS* history & $35(55 \%)$ \\
Preeclampsia & $4(6 \%)$ \\
HELLP $^{\dagger}$ & $1(1.6 \%)$ \\
Fetal distress & $7(10.9 \%)$ \\
Multiple pregnancy & $1(1.6 \%)$ \\
Pephalopelvic disproportion & $5(7.9 \%)$ \\
Acute abdomen & $2(3.1 \%)$ \\
Placenta previa & $1(1.6 \%)$ \\
Malpresentation & $1(1.6 \%)$ \\
Total & $7(10.9 \%)$ \\
\hline
\end{tabular}

*Cesarean section, themolysis, elevated liver enzymes, low platelet 
Table 3. The localization and size of the non-neoplastic adnexal masses

\begin{tabular}{|c|c|c|c|c|c|c|}
\hline Non-neoplastic & Right & Left & Bilateral & $<5 \mathrm{~cm}$ & $\geq 5 \mathrm{~cm}$ & Total \\
\hline Serous cyst & $1(14 \%)$ & $6(86 \%)$ & 0 & $4(57 \%)$ & $3(43 \%)$ & 7 \\
\hline Corpus luteum & $2(50 \%)$ & $1(25 \%)$ & $1(25 \%)$ & $4(100 \%)$ & 0 & 5 \\
\hline Endometrioma & 0 & $1(100 \%)$ & 0 & 1 & 0 & 1 \\
\hline Hemangioma & $1(100 \%)$ & 0 & 0 & 1 & 0 & 1 \\
\hline Ovarian torsion & $1(100 \%)$ & 0 & 0 & 1 & 0 & 1 \\
\hline
\end{tabular}

Table 4. The localization, size, and management of the neoplastic adnexal masses

\begin{tabular}{|c|c|c|c|c|c|c|c|c|}
\hline Neoplastic & Right & Left & Bilateral & $<5 \mathrm{~cm}$ & $\geq 5 \mathrm{~cm}$ & Cystectomy & USO & Total \\
\hline Mature cystic teratoma & $4(36 \%)$ & $6(55 \%)$ & $1(\% 9)$ & $6(55 \%)$ & $5(45 \%)$ & $10(91 \%)$ & $1(9 \%)$ & 11 \\
\hline Mucinous cystadenoma & $1(20 \%)$ & $4(80 \%)$ & 0 & 0 & $5(100 \%)$ & $2(40 \%)$ & $3(60 \%)$ & 5 \\
\hline Dysgerminoma & 0 & $1(100 \%)$ & 0 & 0 & $1(100 \%)$ & 0 & $1(100 \%)$ & 1 \\
\hline Borderline & 0 & $1(100 \%)$ & 0 & 0 & $1(100 \%)$ & 0 & $1(100 \%)$ & 1 \\
\hline
\end{tabular}

*Unilateral salpingo-oophorectomy

respectively. Cystectomy was performed in all patients with non-neoplastic adnexal masses. Mature cystic teratoma was the most common pathology (11 patients, 17\%) in the neoplastic group. Cystectomy was performed in 10 (91\%) and unilateral salpingo-oophorectomy (USO) in 1 (9\%) of the patients with mature cystic teratoma. Mucinous cystadenoma (5 patients, 8\%) and adenofibroma (3 patients, $5 \%$ ) were other common pathologies. Cystectomy was performed in 2 (40\%) and USO in $3(40 \%)$ women with mucinous cystadenoma. Cystectomy was performed in all women with adenofibroma.

One of the patients (27 years old) underwent USO due to giant mass at the left ovary $(25 \mathrm{~cm})$. Final pathology was dysgerminoma. Lymphadenectomy was not performed in our patient because there was no palpable pelvic lymph node. This patient was out of follow-up, and applied to our center with recurrence 1 year later. USO was performed in 1 patient (36 years old) with a borderline mucinous tumor.

Perioperative complications did not develop in our patients who underwent ovarian surgery during cesarean section. Erythrocyte suspension was transfused in 4 patients (6\%). Subtotal hysterectomy was performed in 1 patient due to uterine atony.

\section{Discussion}

In this study, the rate of incidental adnexal mass during cesarean section was found as $0.9 \%$. In previous studies, the incidence of adnexal masses encountered during cesarean section was reported as $0.3-1.64 \%$ (7-10). Adnexal masses can be diagnosed more frequently and easily during pregnancy, comparing the past with the use of ultrasonography in routine follow-up. Despite this, in a study in which almost all patients (99\%) were followed up prenatally, it was seen that only $29.7 \%$ of adnexal masses could be diagnosed before cesarean section (6). Similarly, Baser et al. (7) reported that only $45 \%$ of adnexal masses observed at cesarean section were diagnosed during the prenatal follow-up.

The most common adnexal pathologies in non-neoplastic group were found as paratubal or paraovarian cysts, simple serous cysts, and corpus luteum cysts. Our findings were found to be consistent with previous studies (8). In contrast to $\mathrm{Yu}$ et al. (6), we did not observe theca lutein cysts or endometrioma as more frequent than other types. Simple serous cysts and the majority of corpus luteum cysts, especially uni-loculated ones, may undergo spontaneous resolution after the first trimester of pregnancy, as well as in the pre-pregnancy period. Although paratubal or 
paraovarian cysts are benign, they can be observed relatively more frequently during cesarean section because of their higher persistence rates. Cystectomy or cyst aspiration can be performed during cesarean section for persistent simple serous or corpus luteum cysts (8).

The most common adnexal mass in the neoplastic group was found as mature cystic teratoma (6,9-11). Dermoid cyst, also known as mature cystic teratoma, can be diagnosed using transvaginal ultrasonography by experienced clinicians. However, some reasons like solid nature of the adnexal mass, change of mass location to the Douglas in pregnancy, and same echogenicity with fat tissue may lead to difficulty in its diagnosis at later weeks of gestation. In addition, we observed mucinous cystadenoma and adenofibroma most frequently in the neoplastic benign group. In cases of cystadenoma of $5 \mathrm{~cm}$ and larger, when frozen section cannot be performed, the clinician may prefer salpingo-oopherectomy instead of cystectomy due to malignancy concerns.

Li and Yang (12) reported the incidence of incidental malignant or borderline adnexal mass as $0.21 \%$ in cesarean section. In another study, malignancy was reported in $1 \%$ of simple adnexal masses and 9\% of complex ones were diagnosed during pregnancy (1). As the most common ovarian malignancies in pregnancy, granulosa cell tumor and cystadenocarcinoma have been reported $(7,13)$. We only observed borderline ovarian tumor in 1 of our patients $(1.5 \%)$.

While ovarian dysgerminoma is seen less than $1 \%$ of all ovarian neoplasms, it constitutes $33 \%$ of malignant germ cell tumors (14). It benefits from surgery in the early stages and from chemotherapy in the later stages. Pathology of a patient who underwent salpingo-oopherectomy in our study was reported as stage IA dysgerminoma. In the study of Qin et al. (15), it was shown that per-operative lymphadenectomy did not make a difference in terms of survival in patients receiving adjuvant chemotherapy in stage 1 and 2 dysgerminomas.

When an adnexal mass is diagnosed during pregnancy, its management is controversial. Persistent adnexal masses may be malignant, as well as with increased risk of torsion, bleeding or rupture. Transvaginal ultrasonography and spectral, color Doppler ultrasonography are useful for differential diagnosis (16). For further evaluation, pelvic magnetic resonance imaging without contrast is a good option for characterization of complex adnexal masses to exclude malignancy $(17,18)$. Elective surgery can be performed for persistent adnexal masses $>5 \mathrm{~cm}$ or complex cysts which have a high malignancy risk during the second trimester $(5,19)$. The duration of surgery and hospital stay were found to be shorter in patients who underwent laparoscopy compared to those who underwent laparotomy (20). Torsion in adnexal masses $>5 \mathrm{~cm}$ without elective surgery can cause serious morbidity and requires urgent surgical intervention. There was $1(1.6 \%)$ case of torsion in our patient group with a similar frequency to previous studies (6). We do not know the exact incidence as the patients who were operated due to torsion during follow-up were not included in our study.

\section{Study Limitations}

We have some limitations in this study. First of all, the retrospective nature of the study may prevent the evaluation of all cases. The patients had a pathology material included, so we could not know the exact number of all cysts encountered during cesarean section. We had a relatively small size of the study population.

\section{Conclusion}

Surgical intervention for incidental adnexal masses during cesarean section did not seem to increase the risk of complications. Depending on the characteristics of the detected mass, cystectomy or salpingo-oophorectomy can be performed for incidental adnexal masses during cesarean section. This approach may prevent further surgery after cesarean section in most of the patients.

\section{Ethics}

Ethics Committee Approval: Ethical approval was obtained from Gaziosmanpasa Training and Research Hospital (no: 135, 2020).

Informed Consent: Informed consent of patient was not obtained because it was a retrospective study.

Peer-review: Externally peer-reviewed.

\section{Authorship Contributions}

Concept: C.A., Design: C.A., Data Collection or Processing: C.A., S.Y., Analysis or Interpretation: S.Y., Writing: C.A., S.Y.

Conflict of Interest: No conflict of interest was declared by the authors.

Financial Disclosure: The authors declared that this study received no financial support. 


\section{References}

1. Webb KE, Sakhel K, Chauhan SP, Abuhamad AZ. Adnexal mass during pregnancy: a review. Am J Perinatol 2015;32(11):1010-1016.

2. Oheler MK, Wain GV, Brand A. Gynaecological malignancies in pregnancy: a review. Aust N Z J Obstet Gynaecol 2003;43:414-420.

3. Nazer A, Czuzoj-Shulman N, Oddy L, Abenhaim HA. Incidence of maternal and neonatal outcomes in pregnancies complicated by ovarian masses. Arch Gynecol Obstet 2015;292(5):1069-1074.

4. Whitecar P, Turner S, Higby K. Adnexal masses in pregnancy: A review of 130 cases undergoing surgical management. Am J Obstet Gynecol 1999;181(1):19-24.

5. Balthazar U, Steiner AZ, Boggess JF, Gehrig PA. Management of a persistent adnexal mass in pregnancy: what is the ideal surgical approach? J Minim Invasive Gynecol 2011;18(6):720-725.

6. Yu C, Wang J, Lu W, Xie X, Cheng X, Li X. Analysis of adnexal mass managed during cesarean section. Adv Clin Exp Med 2019;28(4):447-452.

7. Baser E, Erkilinc S, Esin S, Togrul C, Biberoglu E, Karaca MZ, et al. Adnexal masses encountered during cesarean delivery. Int J Gynaecol Obstet 2013;123(2):124-126.

8. Cengiz H, Kaya C, Ekin M, Yeşil A, Yaşar L. Management of incidental adnexal masses on caesarean section. Niger Med J 2012;53(3):132-134.

9. Ulker V, Gedikbasi A, Numanoglu C, Saygi S, Aslan H, Gulkilik A. Incidental adnexal masses at cesarean section and review of the literature. J Obstet Gynaecol Res 2010;36(3):502-505.

10. Güler A E, Güler Demirel Z Ç, Kinci Şehirli Ö. Sezaryen doğumda persistan adneksiyal kitlelerin yönetimi. Perinatoloji Dergisi 2019;27(2):56-61.

11. Dede M, Yenen MC, Yilmaz A, Goktolga U, Baser I. Treatment of incidental adnexal masses at cesarean section: a retrospective study. Int J Gynecol Cancer 2007;17(2):339-341.
12. Li X, Yang X. Ovarian Malignancies Incidentally Diagnosed During Cesarean Section: Analysis of 13 Cases. Am J Med Sci 2011;341(3):181-184.

13. Wróbel A, Rechberger E, Magnowska M, Banach P, Filipczak A, Nowak-Markwitz E, et al. Rak jajnika w ciazy--opisy trzech przypadkóworazaktualnealgorytmy postepowania diagnostycznoterapeutycznego [Ovarian cancer during pregnancy--presentation of three cases and current diagnostic and treatment algorithms]. Ginekol Pol 2015;86(11):872-878.

14. Smith HO, Berwick M, Verschraegen CF, Wiggins C, Lansing L, Muller CY, Qualls CR. Incidence and survival rates for female malignant germ cell tumors. Obstet Gynecol 2006;107(5):10751085.

15. Qin B, Xu W, Li Y. The impact of lymphadenectomy on prognosis and survival of clinically apparent early-stage malignant ovarian germ cell tumors. Jpn J Clin Oncol 2020;50(3):282-287.

16. American College of Obstetricians and Gynecologists' Committee on Practice Bulletins-Gynecology. Practice Bulletin No. 174: Evaluation and Management of Adnexal Masses. Obstet Gynecol 2016;128(5):e210-e226.

17. Thomassin-Naggara I, Fedida B, Sadowski E, Chevrier MC, Chabbert-Buffet N, Ballester M, et al. Complex US adnexal masses during pregnancy: Is pelvic MR imaging accurate for characterization? Eur J Radiol 2017;93:200-208.

18. Yacobozzi M, Nguyen D, Rakita D. Adnexal masses in pregnancy. Semin Ultrasound CT MR 2012;33(1):55-64.

19. Senarath S, Ades A, Nanayakkara P. Ovarian cysts in pregnancy: a narrative review. J Obstet Gynaecol 2020:1-7.

20. Shigemi D, Aso S, Matsui H, Fushimi K, Yasunaga H. Safety of Laparoscopic Surgery for Benign Diseases during Pregnancy: A Nationwide Retrospective Cohort Study. J Minim Invasive Gynecol 2019;26(3):501-506. 